\title{
Long Term Trends in Sulphur and Nitrogen Deposition in Europe and the Cause of Non-linearities
}

\author{
David Fowler • Rognvald Smith • Jennifer Muller • \\ John Neil Cape $\cdot$ Mark Sutton • \\ Jan Willem Erisman • Hilde Fagerli
}

Received: 17 June 2005 / Accepted: 14 January 2006/ Published online: 16 February 2007

(C) Springer Science + Business Media B.V. 2007

\begin{abstract}
Emissions of sulphur and oxidized nitrogen compounds in Europe have been reduced following a series of control measures during the last two decades. These changes have taken place during a period in which the primary gases and the wet deposition throughout Europe were extensively monitored. Since the end of the 1970s, for example land based sulphur emissions declined by between 90 and $70 \%$ depending on the region. Over the same period the total deposition of sulphur and its partitioning into wet and dry deposition have declined, but the spatial pattern in the reduction in deposition differs from that of emission and has changed with time. Such nonlinearities in the emission-deposition relationship are important to understand as they complicate the process of assessing the effects of emission reduction strategies. Observed non-linearities in terrestrial sulphur emission-deposition patterns have been identi-
\end{abstract}

D. Fowler $(\bowtie) \cdot$ R. Smith $\cdot$ J. Muller $\cdot$ J. N. Cape $\cdot$

M. Sutton

Centre for Ecology and Hydrology, Bush Estate,

Edinburgh, Scotland EH26 0QB, UK

e-mail: dfo@ceh.ac.uk

J. W. Erisman

Energy research Centre of The Netherlands,

P.O.Box 1, 1755 ZG Petten, The Netherlands

H. Fagerli

Norwegian Meteorological Institute,

P.O. Box 43, Blindern, 0313 Oslo, Norway fied in north west Europe due to increases in marine emissions, and are currently slowing the recovery of freshwater ecosystems. Changes in the relative amounts of $\mathrm{SO}_{2}$ and $\mathrm{NH}_{3}$ in air over the last two decades have also changed the affinity of terrestrial surfaces for $\mathrm{SO}_{2}$ and have therefore changed the deposition velocity of $\mathrm{SO}_{2}$ over substantial areas. The consequence of this effect has been the very rapid reduction in ambient $\mathrm{SO}_{2}$ concentration in some of the major source areas of Europe, where $\mathrm{NH}_{3}$ did not change much. Interactions between the different pollutants, generating non-linearities are now being incorporated in long-range transport models to simulate the effects of historical emission trends and to provide projections into the future. This paper identifies non-linearities in emission deposition relationships for sulphur and nitrogen compounds in Europe using data from the EMEP long-rang transport model and measured concentration fields of the major ions in precipitation and of $\mathrm{SO}_{2}$ and $\mathrm{NO}_{2}$ in surface air.

Keywords nitrogen · non-linearity · shipping · sulphur - wet and dry deposition

\section{Introduction}

The control of acidifying pollutant emissions in Europe has progressed steadily since the early 1980s, when the first steps to control sulphur emissions were introduced 
(Brydges \& Wilson, 1991). The main focus of the early control measures was sulphur, as the major contributor to acidification of terrestrial ecosystems in Europe (Johnson \& Reuss, 1984). Following these early steps in the process, emission controls were extended to nitrogen compounds, with a clear focus on oxidized nitrogen and to volatile organic compounds (VOC) to broaden the control strategy from acidification to include ground level ozone. The most recent UNECE Protocol (Gothenburg) and related Directives from the European Commission extended the degree of control of emissions leading to acidification and included eutrophication and ground level ozone and includes targets for $\mathrm{NH}_{3}$. An up to date summary of the control measures in Europe and emerging air quality issues is provided by Grennfelt and Hov (2005). The reductions in pollutant emissions vary considerably in time and space throughout Europe, furthermore the extent of the controls on the different pollutants varied greatly, with very large reductions in emissions of $\mathrm{SO}_{2}$ but only modest reductions in $\mathrm{NH}_{3}$ emissions. The pollutants concerned are all reactive in the atmosphere, and differential reductions in emissions have the potential to cause changes in the source-receptor relationships with time, due for example to changes in the chemical processing and deposition of individual pollutants. Improvements in air quality may therefore be more variable spatially than expected on the basis of a strictly linear decline in deposition with a constant spatial pattern in deposition following emission reductions.

In the case of sulphur, emitted in the gaseous state as $\mathrm{SO}_{2}$, the oxidation occurs either in the gas phase through reaction with $\mathrm{OH}$ or by heterogeneous processes in clouds or in aerosols and in this case the $\mathrm{pH}$ of the droplet strongly influences the reaction pathway and the preferred oxidant. The most important base regulating the acidity of cloud droplets over Europe is $\mathrm{NH}_{3}$, thus emissions of $\mathrm{NH}_{3}$ have the potential to regulate the oxidation pathway of $\mathrm{SO}_{2}$ (Wayne, 1985) and therewith the transport distance of $\mathrm{SO}_{2}$.

Non-linearities may also occur through changes in the terrestrial sink for key pollutants with time. In the case of $\mathrm{SO}_{2}$, the deposition velocity in polluted regions of Europe has been increasing with time as the amounts of $\mathrm{SO}_{2}$ have declined relative to ambient $\mathrm{NH}_{3}$ concentration, allowing the surface resistance for $\mathrm{SO}_{2}$ to decline substantially (Erisman et al., 1998, 2001; Fowler et al., 2001).
Potential non-linearities in source-receptor relationships were identified by Clark et al in the 1980s (Clark, Fisher, \& Scriven, 1987). But at that time the magnitude of emission reductions was small relative to overall emissions and the available data series was short and geographically limited. The projected nonlinearities were not therefore subjected to a significant test against long-term measurements of concentration and deposition fields. More recently, non-linearities in source receptor matrices computed with the EMEP model have been examined by Bartnicki (2000) who concluded that non-linearities were greatest for oxidized nitrogen and increased with distance between source and receptor and were also largest for pollutants with the smallest rates of deposition.

However, the study by Bartniki was limited to numerical experiments and the available data in Europe now provides broad coverage at continental scales of the concentrations of the major ions in precipitation and hence wet deposition for in excess of 20 years (Tarrason et al., 2004). The monitoring also includes gaseous $\mathrm{SO}_{2}$ and for much of the area $\mathrm{NO}_{2}$. Other important gases including $\mathrm{HNO}_{3}$ and $\mathrm{NH}_{3}$ are not monitored separately throughout Europe, and continuous monitoring of dry deposition is limited to a few locations in The Netherlands, Germany and the UK (Erisman et al., 1998).

Examination of the long term trends in emission and deposition in the UK has revealed substantial non-linearities in sulphur deposition, which are caused by a combination of increasing rates of $\mathrm{SO}_{2}$ dry deposition and increasing imports of sulphur to the UK from shipping activities in the eastern Atlantic Ocean (Endresen et al., 2003).

The purpose of this paper is to examine the long term trends in emission and deposition at the regional scale in Europe using data from the EMEP model and measured gaseous and precipitation concentration fields throughout Europe in the period 1980-2000.

The background of the paper is the substantial reduction in emission of the primary pollutants $\mathrm{SO}_{2}$, NOx and $\mathrm{NH}_{3}$ between 1980 and the present, summarised in Fig. 1.

\section{Materials and Methods}

The analysis is in two parts, first an examination of the trends in emission and deposition for sulphur, 


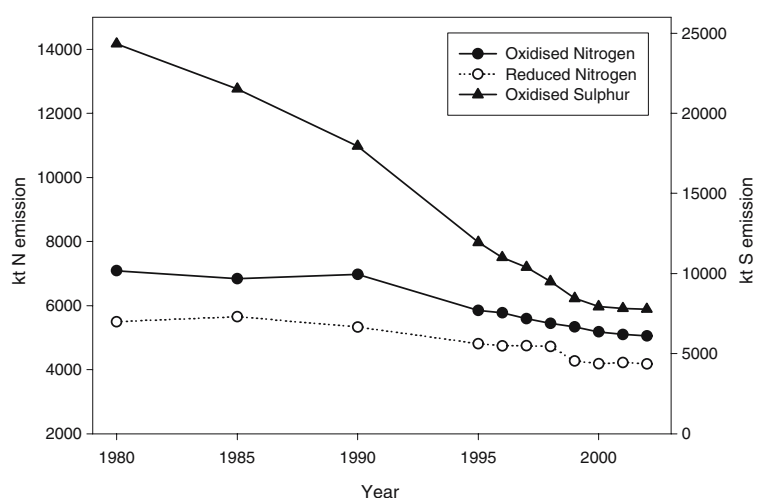

Fig. 1 Emissions of Sulphur, oxidised and reduced Nitrogen in the EMEP domain between 1980 and 2000

oxidized and reduced nitrogen from the EMEP model for the period 1980-2000 in five regions of Europe, roughly separated by their emission-deposition patterns into two source regions in which the emissions exceed the deposition and three receptor regions in which the deposition exceeds emissions within the zone by an incrementally larger fraction (Fig. 2).

The second part of the analysis is a comparison of emissions within the five zones with measured trends in concentrations of the relevant ions in precipitation, $\mathrm{SO}_{4}^{2-}, \mathrm{NO}_{3}^{-}$and $\mathrm{NH}_{4}^{+}$, and with ambient concentrations of $\mathrm{SO}_{2}$ and $\mathrm{NO}_{2}$.

Measured Concentrations (annual Means) were allocated to the zones 1-5 shown in Fig. 3. Data were used only when data capture exceeded $>75 \%$ of the sampling period. Annual mean values for each region for all years were calculated for sites with a

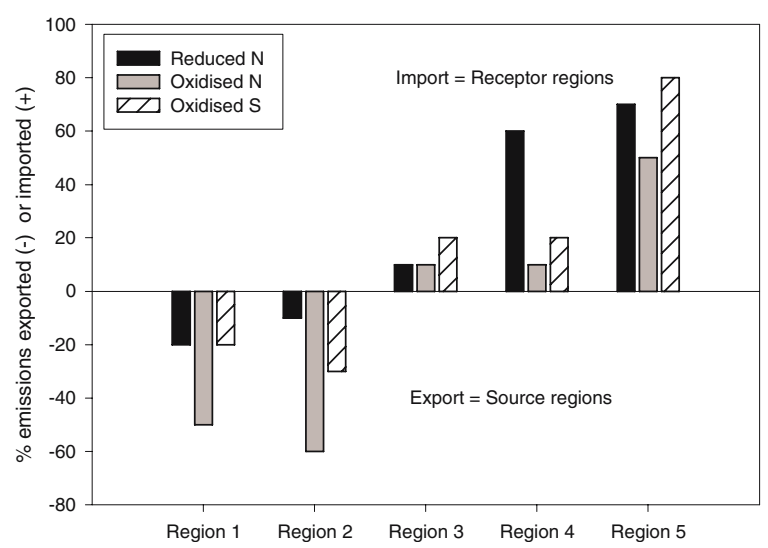

Fig. 2 Percentage of emissions exceeding deposition in source regions ( $\%$ of emission exported) and percentage of deposition exceeding emission in receptor regions (\% of emission imported) data record of 10 years or more (allowing discontinuities). For trends (1980-2000), for both gaseous and liquid phase concentrations, the changes over the 20-year period were calculated from linear trend analysis as the average over the region.

Emission and deposition within each of the zones were calculated from the total deposition for whole domain allocated to each grid square to its region.

The overall mass balance over the entire EMEP domain (Fig. 4) shows emissions of sulphur approximately $10 \%$ smaller than deposition, indicating a net import to the domain, or a significant underestimate of emissions or overestimate of deposition, or a combination of the two. The marine emissions of sulphur were held constant in the model, yet recent studies of marine sulphur emissions shows a steady increase over the 20-year period (Derwent et al., 2005). Emissions and deposition of reduced nitrogen remain in close balance over the domain over the 20year period. For oxidized nitrogen emissions exceed deposition throughout the period, indicating a net export from Europe to the east. However, the net export in 1980 equivalent to $10 \%$ of emissions has grown to $20 \%$ by 2000 , and shows a substantial export of oxidized nitrogen to the east of the EMEP domain. The extent to which this apparent growth in exported nitrogen is the consequence of a growing contribution from shipping is not quantified in this analysis. It is possible that the entire growth is due to shipping sources, a priority area of further work.

\section{Comparisons Between Emissions and Deposition in the Source and Receptor Regions of Europe 1980-2000 Using EMEP Model Data}

\subsection{Source Regions}

In these regions, comprising the highly populated region of northern Europe stretching from the Czech Republic in the East to SE England in the West, emissions exceed deposition for all pollutants considered, by between 10 and $60 \%$ (Table 1). Over the 20year period emissions of sulphur decline by between 70 and $80 \%$ and deposition declines by a similar amount averaging $75 \%$ for the two regions (Table 2).

Similarly for oxidized and reduced nitrogen the reduction in emissions is close to the reduction in deposition at $20 \%$ for reduced nitrogen and $40 \%$ for 
Fig. 3 EMEP grid divided into five regions

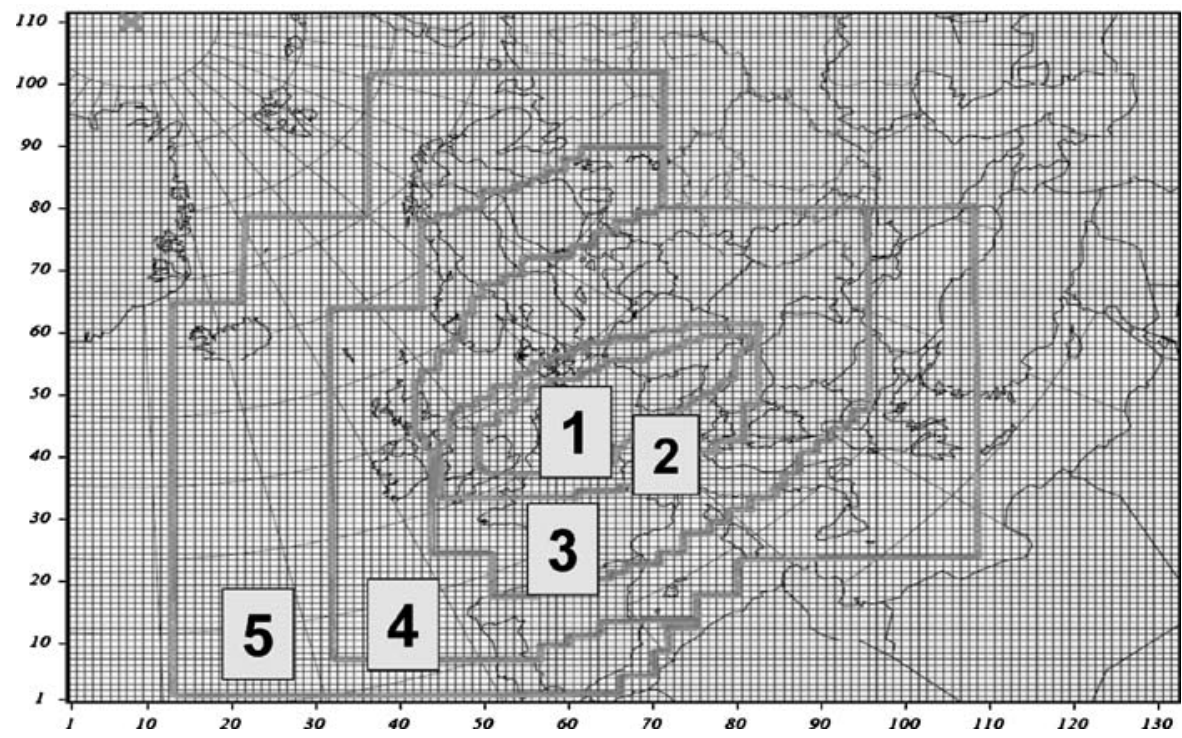

between 40 and $80 \%$ in 1980 declining to $10-60 \%$ in 2000 , there is a marked decline in advection into the region over the 20 years. However, these regions are still receiving substantially more deposition than the total of the emissions within the regions. The emissions declines for all three pollutants in the zone are smaller than the deposition declines, showing the effect of the greater reduction in the pollutant imported into the region. For zone 5 in which deposition exceeds emissions by between 80 and $150 \%$ for sulphur and reduced nitrogen, respectively, the deposition within the region is very sensitive to changes in sources upwind, and the decline in emissions within the region are smaller than the
Fig. 4 The mass budget for Sulphur and oxidised Nitrogen for 2000 showing a balance of emission and deposition, net import of sulphur into the domain and a net export of oxidised Nitrogen, figures in MTonnes $\mathrm{S}$ or $\mathrm{N}$

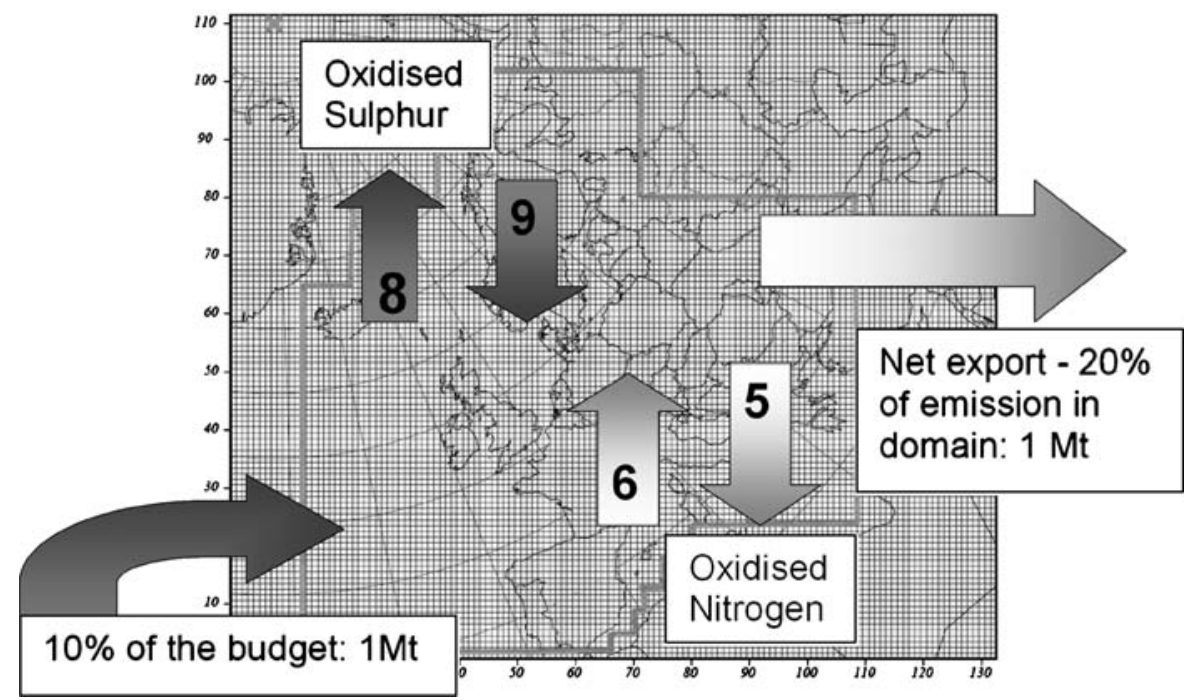


Table 1 Percentage by which emission exceeds pollutant deposition in zones 1 and 2 (zones from Fig. 3)

\begin{tabular}{llll}
\hline & $\begin{array}{l}\text { Reduced } \\
\text { Nitrogen(\%) }\end{array}$ & $\begin{array}{l}\text { Oxidised } \\
\text { Nitrogen }\end{array}$ & $\begin{array}{l}\text { Oxidised } \\
\text { Sulphur }\end{array}$ \\
\hline Region 1 & 20 & $50 \%$ & $\begin{array}{l}40 \% \text { in } 1980 \\
20 \% \text { in } 2000\end{array}$ \\
Region 2 & 10 & $\begin{array}{l}40 \% \text { in } 1980 \\
60 \% \text { in } 2000\end{array}$ & \\
& & &
\end{tabular}

decline in deposition for both oxidized and reduced nitrogen.

\section{Comparing Measured Concentrations in Air and Rain With Trends in Emissions}

In this section, trends in emissions since 1980 are compared with trends in measured concentrations of $\mathrm{SO}_{4}^{2-}, \mathrm{NO}_{3}^{-}$and $\mathrm{NH}_{4}^{+}$in precipitation and gaseous $\mathrm{NO}_{2}$, and $\mathrm{SO}_{2}$ from the EMEP network. In this case the trends are considered by pollutant.

\subsection{Reduced Nitrogen}

The emissions of ammonia declined by $23 \%$ over the 20 years over the entire domain, but there are different trends in the different zones (Fig. 5). Emissions decline by $20-30 \%$ in the source regions and much smaller reductions are observed in the receptor regions, of $6 \%$ in zone 4 and a small increase in emissions in zone 5 of $10 \%$. The concentrations of $\mathrm{NH}_{4}^{+}$in rain decline in the source regions fairly closely in proportion to the emission reductions. In the receptor regions concentrations of $\mathrm{NH}_{4}^{+}$increase during the 20 years, although from very small values, consistent qualitatively with changes in emissions within the zone.

Table 2 Changes in emission and deposition from 1980-2000, expressed as percentage in regions 1 and 2 (in relation to 1980 value)

\begin{tabular}{|c|c|c|c|c|}
\hline & \multicolumn{2}{|l|}{ Emission } & \multicolumn{2}{|c|}{ Deposition } \\
\hline & $\begin{array}{l}\text { Region } \\
1 \text { in }(\%)\end{array}$ & $\begin{array}{l}\text { Region } \\
2 \text { in }(\%)\end{array}$ & $\begin{array}{l}\text { Region } \\
1 \text { in }(\%)\end{array}$ & $\begin{array}{l}\text { Region } \\
2 \text { in }(\%)\end{array}$ \\
\hline Reduced Nitrogen & -29 & -22 & -18 & -18 \\
\hline Oxidised Nitrogen & -41 & -31 & -36 & -34 \\
\hline Oxidised Sulphur & -83 & -73 & -77 & -73 \\
\hline
\end{tabular}

Table 3 Changes in emission and deposition from 1980-2000 in Region 3, expressed as percentage (in relation to 1980 value)

\begin{tabular}{lll}
\hline & Emission in (\%) & Deposition in (\%) \\
\hline Reduced Nitrogen & -28 & -23 \\
Oxidised Nitrogen & -29 & -30 \\
Oxidised Sulphur & -61 & -67 \\
\hline
\end{tabular}

\subsection{Oxidized Nitrogen}

Emissions decline in the source regions by between 30 and $40 \%$ over the 20 years (Fig. 6). By contrast emissions in the remote regions decline by a smaller amount (2\%) in zone 4 and increase by $6 \%$ in zone 5 . The concentrations of $\mathrm{NO}_{3}^{-}$in rain decline by much smaller amounts than the change in emissions, averaging $-22 \%$ in the source regions. In the receptor regions the reductions in concentrations of $\mathrm{NO}_{3}^{-}$in rain are smaller than reductions in emissions in zones 3 by almost a factor of three, and in the remote regions 4 and 5 , concentrations increase by typically $50 \%$. Ambient concentrations of $\mathrm{NO}_{2}$ (Table 4) change in all regions except region 4 by amounts that are similar to the changes in emissions within the zone.

\subsection{Sulphur}

Emissions of sulphur decline in all zones, by $83 \%$ in zone 1 declining through the different zones to $52 \%$ in zone 5 over the 20 years. The concentrations of $\mathrm{SO}_{2}$ also decline, and by amounts that consistently exceed the reductions in emissions (Fig. 7). The concen-

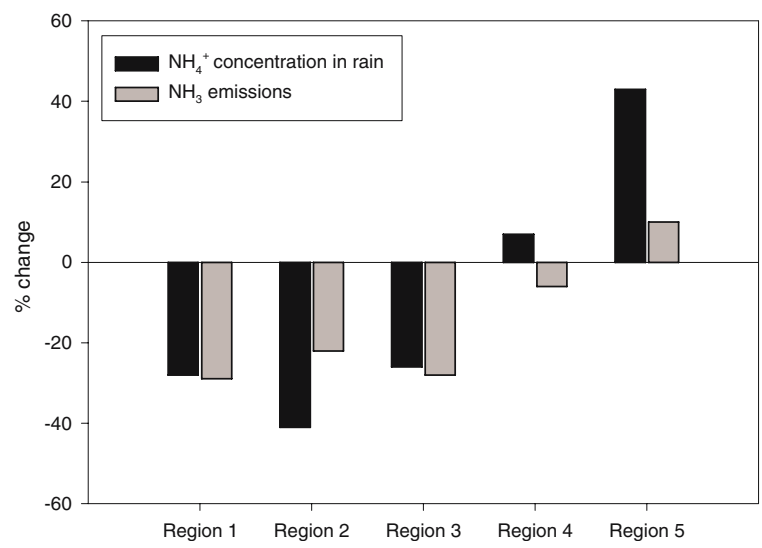

Fig. 5 Changes in $\mathrm{NH}_{4}^{+}$in precipitation from 1980-2000, expressed as percentage of change relative to 1980 


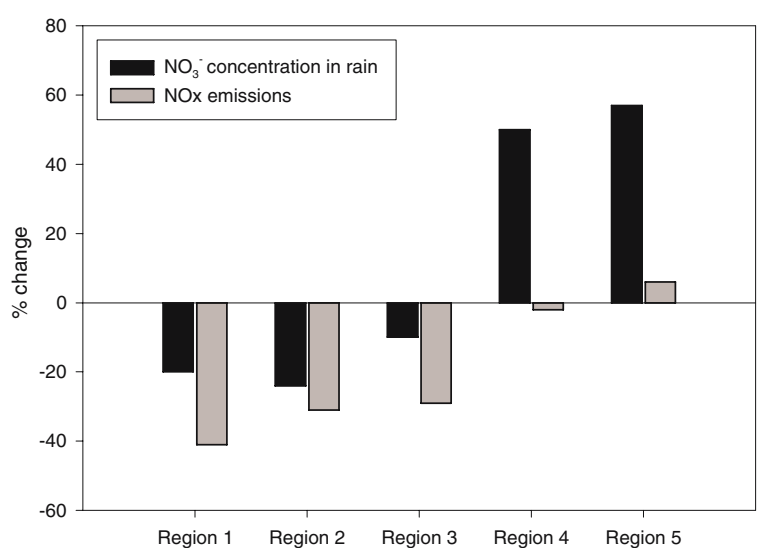

Fig. 6 Changes in $\mathrm{NO}_{3}^{-}$in precipitation from 1980-2000, expressed as percentage of change relative to 1980

trations of $\mathrm{SO}_{4}^{2-}$ in rain also decline in all zones and in this case consistently by smaller amounts than the reduction in emissions, by amounts that exceed the reduction in emissions by $10-30 \%$ (Fig. 7).

\section{Discussion}

The comparison of emissions and deposition within the zones defined in this paper using the EMEP model data show a close correspondence of the values in the source areas for both oxidized and reduced nitrogen and for sulphur. In the remote regions the correspondence between emission and deposition is close for sulphur but some differences for oxidized and reduced nitrogen are apparent, showing the greater importance of long range transport to the deposition budgets of these regions. However, taken as a whole the picture generated by these data is one of an approximately linear system in which the trends in emission and deposition broadly follow the trends in deposition.

When the field measurements of concentrations of the pollutants in gas phase and in precipitation are considered, a rather different picture emerges. In the case of reduced nitrogen the measured concentrations

Table 4 Changes in $\mathrm{NO}_{2}$ in air from 1990-2000, expressed as percentage of change relative to 1990

\begin{tabular}{lllll}
\hline & $\begin{array}{l}\text { Region 1 } \\
\text { in }(\%)\end{array}$ & $\begin{array}{l}\text { Region 2 } \\
\text { in (\%) }\end{array}$ & $\begin{array}{l}\text { Region 3 } \\
\text { in (\%) }\end{array}$ & $\begin{array}{l}\text { Region 4 } \\
\text { in (\%) }\end{array}$ \\
\hline$\Delta \mathrm{NO}_{2}$ in air & -37 & -31 & -21 & -29 \\
$\Delta$ Emission & -33 & -30 & -30 & -9 \\
\hline
\end{tabular}

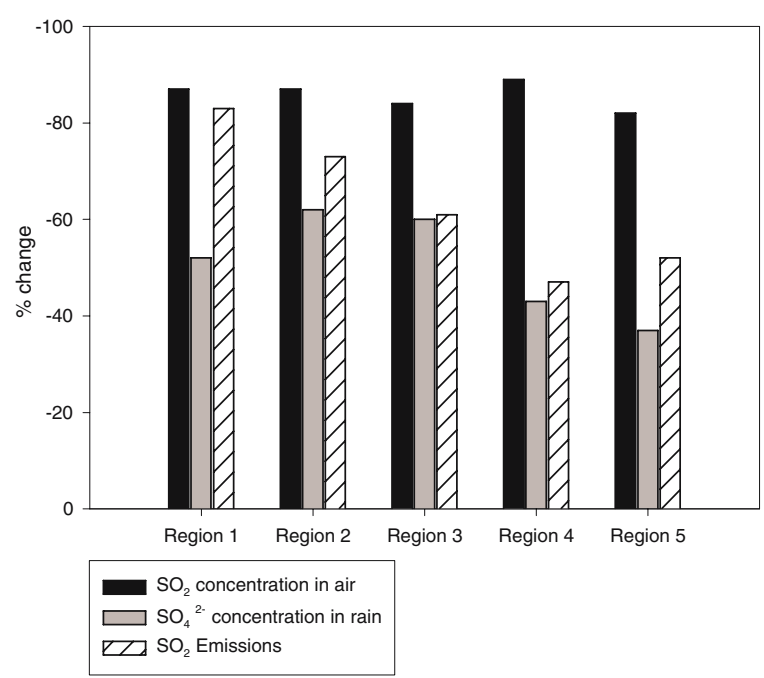

Fig. 7 Changes of $\mathrm{SO}_{2}$ in air, non-sea salt $\mathrm{SO}_{4}^{2-}$ in precipitation and $\mathrm{SO}_{2}$ emissions, expressed as percentage of change relative to 1980

of $\mathrm{NH}_{4}^{+}$and the emissions follow broadly similar trends over the majority of the domain, although there is a clear, increase in concentrations in the remote regions, even though the absolute values are small. For oxidized nitrogen there are clear non-linearities in the responses of deposition to the emission reductions over the 20 years. Concentrations of $\mathrm{NO}_{2}$ follow the decline in emissions, but the reductions in $\mathrm{NO}_{3}^{-}$ concentrations in precipitation are much smaller than emission reductions, with some areas with reductions in emissions of $40 \%$ showing a reduction in concentrations in precipitation of $20 \%$. In the remote regions emission reductions are much smaller, and in these regions the concentrations of $\mathrm{NO}_{3}^{-}$are increasing. Over the two remote regions the concentrations, while small have increased by about $50 \%$ over the 20 -year period and might be important for species adapted to a very limited atmospheric nitrogen supply. Thus for oxidized nitrogen there are large non-linearities, and these while indicated by the model data are much more pronounced in measurements than in the model. The observations of non-linearities in the oxidized nitrogen budget are consistent with observations at the country scale, with very much smaller reductions in the deposition of oxidized nitrogen in the UK than the reduction in emissions (Fowler, Muller, Smith, Cape, \& Erisman, 2005).

The cause of these non-linearities remains a matter for speculation, but at the country scale, the data are consistent with more rapid oxidation of $\mathrm{NO}_{\mathrm{x}}$ to $\mathrm{NO}_{\mathrm{y}}$, 
through both homogeneous oxidation processes with $\mathrm{OH}$ as the oxidant, and the steady increase in mean ozone concentrations (Simmonds, Derwent, Manning, \& Spain, 2004) is consistent with this explanation, at least qualitatively. The oxidation of $\mathrm{NO}_{\mathrm{x}}$ to $\mathrm{NO}_{\mathrm{y}}$ in the large urban conurbations at night represent another process subject to increases with time over the last decade as urban ozone concentrations have steadily increased.

For sulphur, the mass balance over the entire domain suggests the importance of additional sources outside the region, or that emissions have been underestimated. From the recent publications on increasing shipping sulphur emissions over the period 1980-2000, it seems probable that shipping emissions have been underestimated (Corbett \& Koehler, 2003; Endresen et al., 2003). There are clear nonlinearities, with ambient concentrations of $\mathrm{SO}_{2}$ declining faster than emissions throughout the domain. The rapid decline in $\mathrm{SO}_{2}$ concentration is entirely consistent with the observation of increasing deposition velocity for $\mathrm{SO}_{2}$ with time as observed by Fowler et al. (2001). The underlying process causing this effect is the steady decline in the $\mathrm{SO}_{2} / \mathrm{NH}_{3}$ concentration ratio which allows the water film on vegetation to remain at a sufficiently high $\mathrm{pH}$ to maintain $\mathrm{SO}_{2}$ uptake at the surface as shown in field data and a process based model by Flechard, Fowler, Sutton, \& Cape, (1999).

The non-linearities in oxidized nitrogen and sulphur emission-deposition budgets are evident across substantial areas of the domain. The consequences for effects assessment can readily quantified when the processes causing the non-linearities have been incorporated in the long-range transport models but are expected to be substantial. Current uncertainties in the processes leading to the non-linearities are therefore priorities for research and model development. The data sets available within Europe, from the networks and from campaign and laboratory measurements provide a key resource, but the main focus should be on the further, careful analysis of the field measurements and the development of the models to reproduce the observed trends.

Acknowledgements The Authors gratefully acknowledge the financial support of the European Commission through the NEPAP project and the UK Department for the Environment, Food and Rural Affairs (Defra) in contracts (EPG1/3/166).

\section{References}

Bartnicki, J. (2000). Non-linear effects in the source-receptor matrices computed with the EMEP Eulerian acid deposition model. pp 34 EMEP/MSC-W Note 4/00.

Clark, P. A., Fisher, B. E. A., \& Scriven, R. A. (1987). The wet deposition of sulphate and its relationship to sulphur dioxide emissions. Atmospheric Environment, 21, 1125-1131.

Corbett, J. J., \& Koehler, H. W. (2003). Updated emissions from ocean shipping. Journal of Geophysical Research, 108, 4650, doi http://dx.doi.org/10.1029/2003JD003751.

Brydges, T. G., \& Wilson, R. B. (1991). Acid rain since 1985times are changing. Proceedings of the Royal Society of Edinburgh B, 97, 1-16.

Derwent, R. G., Stevenson, D. S., Doherty, R. M., Collins, W. J., Sanderson, M. G., Johnson, C. E., et al. (2005). The contribution from shipping emissions to air quality and acid deposition in Europe. Ambio, 34, 54-59.

Endresen, O., Sorgard, E., Sundet, J. K., Dalsoren, S. B., Isaksen, I. S. A., Berglen, T. F., et al. (2003). Emission from sea transportation and environmental impact. Journal of Geophysical Research, 108, 4650, doi http://dx.doi.org/ 10/2002JD002898.

Erisman, J. W., Hensen, A., Fowler, D., Flechard, C. R., Grüner, A., Spindler, G., et al. (2001). Dry deposition monitoring in Europe. Water, Air, and Soil Pollution, Focus 1, 17-27.

Erisman, J. M., Mennen, M. G., Fowler, D., Flechard, C. R., Spindler, G., Gruner, A., et al. (1998). Deposition monitoring in Europe. Environmental Monitoring and Assessment, 53, 279-295.

Flechard, C. R., Fowler, D., Sutton, M. A., \& Cape, J. N. (1999). A dynamic chemical model of bi-directional ammonia exchange between semi-natural vegetation and the atmosphere. Quarterly Journal of the Royal Meteorological Society, 125, 1-33.

Fowler, D., Muller, J., Smith, R. I., Cape, J. N., \& Erisman, J. W. (2005). Nonlinearities in source receptor relationships for sulphur and nitrogen compounds. Ambio, 34, 41-46.

Fowler, D., Sutton, M. A., Flecard, C., Cape, J. N., StoretonWest, R., Coyle, M., et al. (2001). The control of $\mathrm{SO}_{2}$ dry deposition on to natural surfaces by $\mathrm{NH}_{3}$ and its effects on regional deposition. Water, Air, and Soil Pollution, Focus $1,39-48$.

Grennfelt, P., \& Hov, Ø. (2005). Regional air pollution at a turning point. Ambio, 34, 2-10.

Johnson, D. W., \& Reuss, J. O. (1984). Soil-mediated effects of atmospherically deposited sulphur and nitrogen. Philosphical Transactions of the Royal Society of London. B, 305, 383392.

Simmonds, P., Derwent, R. G., Manning, A. L., \& Spain, G. (2004). Significant growth in surface ozone at mace head, Ireland, 1987-2003. Atmospheric Environment, 38, 47694778 .

Tarrason, L., Fagerli, H., Jonson, J. E., Klein, H., van Loon, M., Simpson, D., et al. (2004). Transboundary acidification, eutrophication and ground level ozone in Europe. EMEP Status Report 1/04, pp. 154.

Wayne, R. P. (1985). Chemistry of atmospheres. New York: Oxford University Press. ( pp. 361) 